\title{
A search in north Greenland for a new ice-core drill site
}

\author{
D. Dahl-Jensen, ${ }^{1}$ N. S. Gundestrup, ${ }^{1}$ K. Kellekr, ${ }^{1}$ S. J. Johnsen, ${ }^{1}$ S. P. Gogineni, ${ }^{2}$ C.T. Allen, ${ }^{2}$ \\ T. S. Chuah, ${ }^{2}$ H. Miller, ${ }^{3}$ S. Kipfstuhl, ${ }^{3}$ E. D. Waddington ${ }^{4}$ \\ ${ }^{1}$ University of Copenhagen, Niels Bohr Institute for Astronomy, Physics and Geophysics, Juliane Maries Vej 30, \\ DK-2100 Copenhagen OE, Denmark \\ ${ }^{2}$ The University of Kansas Center for Research, Inc., Radar Systems and Remote Sensing Laboratory, 2291 Irving Hill Road, \\ Lawrence, Kansas 66045-2969, U.S.A. \\ ${ }^{3}$ Alfred Wegener Institute, Columbusstrasse, D-27568 Bremerhaven, Germany \\ ${ }^{4}$ University of Washington, Geophysics Programs, Box 351650, Seattle, Washington 98195, U.S.A.
}

\begin{abstract}
A new deep ice-core drilling site has been identified in north Greenland at $75.12^{\circ} \mathrm{N}, 42.30^{\circ} \mathrm{W}, 316 \mathrm{~km}$ north-northwest (NNW) of the GRIP drill site on the summit of the ice sheet. The ice thickness here is $3085 \mathrm{~m}$; the surface elevation is $2919 \mathrm{~m}$. The North GRIP (NGRIP) site is identified so that ice of Eemian age (115-130 ka BP, calendar years before present) is located as far above bedrock as possible and so the thickness of the Eemian layer is as great as possible. An ice-flow model, similar to the one used to date the GRIP ice core, is used to simulate the flow along the NNW-trending ice ridge. Surface and bedrock elevations, surface accumulation-rate distribution and radio-echo sounding along the ridge have been used as model input. The surface accumulation rate drops from $0.23 \mathrm{~m}$ ice equivalent year ${ }^{-1}$ at GRIP to $0.19 \mathrm{~m}$ ice equivalent year ${ }^{-1} 50 \mathrm{~km}$ from GRIP. Over the following $300 \mathrm{~km}$ the accumulation is relatively constant, before it starts decreasing again further north. Ice thicknesses up to $3250 \mathrm{~m}$ bring the temperature of the basal ice up to the pressure-melting point $100-250 \mathrm{~km}$ from GRIP. The NGRIP site is located $316 \mathrm{~km}$ from GRIP in a region where the bedrock is smooth and the accumulation rate is $0.19 \mathrm{~m}$ ice equivalent year ${ }^{-1}$. The modeled basal ice here has always been a few degrees below the pressure-melting point. Internal radio-echo sounding horizons can be traced between the GRIP and NGRIP sites, allowing us to date the ice down to $2300 \mathrm{~m}$ depth (52 ka BP). An ice-flow model predicts that the Eemian-age ice will be located in the depth range $2710-2800 \mathrm{~m}$, which is $285 \mathrm{~m}$ above the bedrock. This is $120 \mathrm{~m}$ further above the bedrock, and the thickness of the Eemian layer of ice is $20 \mathrm{~m}$ thicker, than at the GRIP ice-core site.
\end{abstract}

\section{INTRODUCTION}

In 1992 93, two deep ice cores were completed in central Greenland; the European GRIP ice core was located on the summit point of the ice sheet $\left(72.60^{\circ} \mathrm{N}, 37.62^{\circ} \mathrm{W}\right.$, elevation $3232 \mathrm{~m}$; Johnsen and others, 1992) and the American GISP2 ice core was drilled $28 \mathrm{~km}$ west of the summit (72.6 $\mathrm{N}, 38.5^{\circ} \mathrm{W}$, elevation $3200 \mathrm{~m}$; Taylor and others, 1993). These two deep ice cores provide paleoclimate information covering the last glacial period $11.5-115 \mathrm{ka}$ BP (calendar years before present) with greater detail than previously obtained from any ice core. The stable-isotope records from the two ice cores agree in the top $90 \%$ of both cores, even for small-scale features (Dansgaard and others, 1993; Grootes and others, 1993; Taylor and others, 1993; Alley and others, 1995). Below depths of $2700 \mathrm{~m}$, however, spanning the Eemian (Sangamonian) interglacial period and the previous glacial, there are significant differences between the two records. These differences are attributed to the disturbance of the simple ice-layer stratigraphy by flow patterns unique to the basal zone of the ice sheet, such as folding (Alley and others, in press; Thorsteinsson and others, in press).

Even though most of the visible disturbances seem to be located below the Eemian ice in the GRIP core, the fact that these two cores show different records raises doubts about the integrity of the stratigraphic records through the Eemian interglacial.

Ice cores do provide the best opportunity to produce a high-resolution Eemian record, so we should drill in a location where the Eemian ice is as far above bedrock as possible on the Greenland ice sheet.

An ice core drilled on the Greenland ice sheet in a region where the surface accumulation rate is lower than those at GRIP and GISP2 would produce an ice core where the location of the older ice is further from bedrock. Too low accumulation rates, however, would cause basal temperatures to reach the melting point during the glacial, and should be avoided. In this study the observations and modeling that have led to the selection of a favorable drill site in north Greenland, the North GRIP (NGRIP) site, meeting the specific criteria described above, will be discussed.

\section{SURFACE, BEDROCK TOPOGRAPHY AND ACCU- MULATION RATES IN NORTH GREENLAND}

The surface contour map of north Greenland based on Geosat and ERS-1 satellite data, airborne radar altimetry and airborne laser altimetry (Ekholm and others, 1995; Ekholm, 
1996) provides the most detailed surface topography available covering north Greenland. From the summit of the ice sheet a north-northwest- (NNW-) trending ice ridge is seen to continue $550 \mathrm{~km}$ before it bifurcates (Fig. 1). A second northeast-trending ice ridge also leaves the summit. Results from the ERS-1 synthetic aperture radar imagery (Fahnestock and others, 1993) show an ice stream extending from the Summit region to the north-northeast section of the Greenland ice sheet. The ice that has encountered icestream flow is not suitable for the ice-core site, meeting the criteria of the studies, because the temperature near the bed is close to the melting point. The oldest ice can be melted away and may have been subject to high shear stresses.

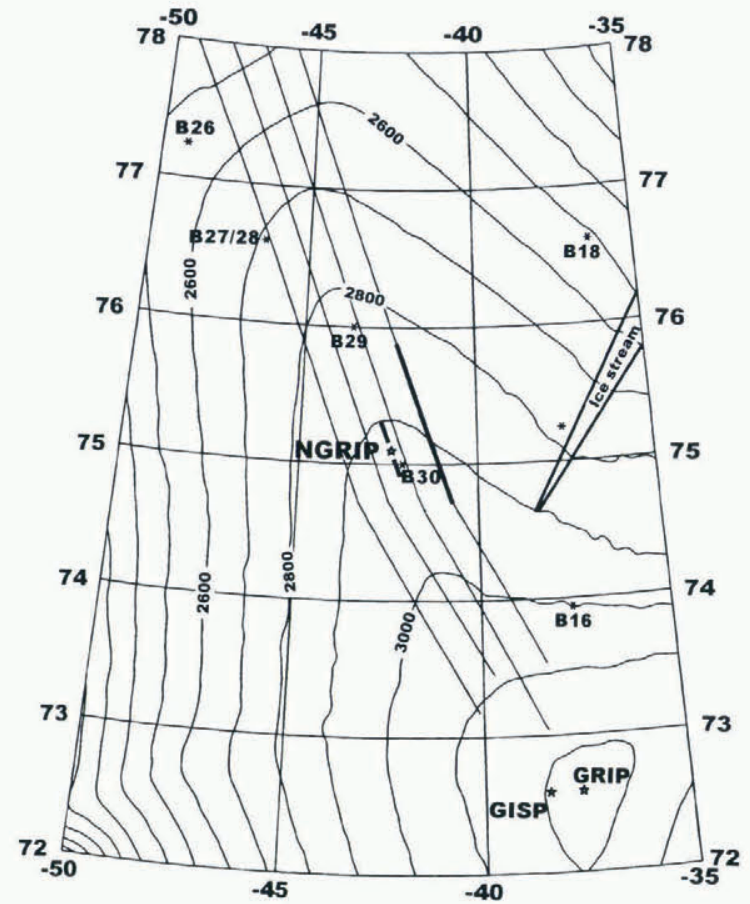

\begin{abstract}
Fig. 1. Map of north Greenland, showing surface contours, and the locations of GRIP, GISP2, NGRIP and the ice stream suggested by Fahnestock and others (1993). Locations where shallow ice cores were drilled in 1994-95 are marked B16-B30. The four parallel lines are the airborne radio-echo lines measured in 1995 by NASA and University of Kansas (Chuah and others, 1996). The $100 \mathrm{~km}$ long thick line east of the NGRIP site is the part of this profile shown in Figure $5 a$, and the other $50 \mathrm{~km}$ long thick line over. NGRIP measured in 1996 is shown in Figure $5 b$.
\end{abstract}

From the surface contour map, the preferred drill site is on the NNW-trending ice ridge. The ice here originally fell as snow on the surface not far from the drill site. This simplifies the interpretation. At the ice ridge the amount of shear stress on the ice is reduced, which will help preserve the stratigraphic layering near the bedrock. A further restriction of the acceptable area arises from the criterion that the central part of the ice sheet has undergone the smallest ice-thickness changes under the past glacial. As the Eemian interglacial period had a warmer climate than at present, the size of the ice sheet may have been considerably smaller (Letréguilly and others, 1991a, b; Fabre and others, 1995). This will introduce large ice-thickness changes, especially at sites far from the central part of the ice sheet.
A minimum of bedrock topographic relief should further reduce the risk of bottom layer disturbance. We used the bedrock topography of Letréguilly and others (1991a, b) together with more recent radar measurements of the bedrock in the Summit region Hodge and others, 1990; Jacobel and Hodge, 1995) and along the NNW ice ridge (Chuah and others, 1996). In general the bedrock has undulations of up to $200 \mathrm{~m}$ along the NNW-trending ice ridge (Fig. 2), whereas the region $170-430 \mathrm{~km}$ NNW of the summit has undulations smaller than $100 \mathrm{~m}$.
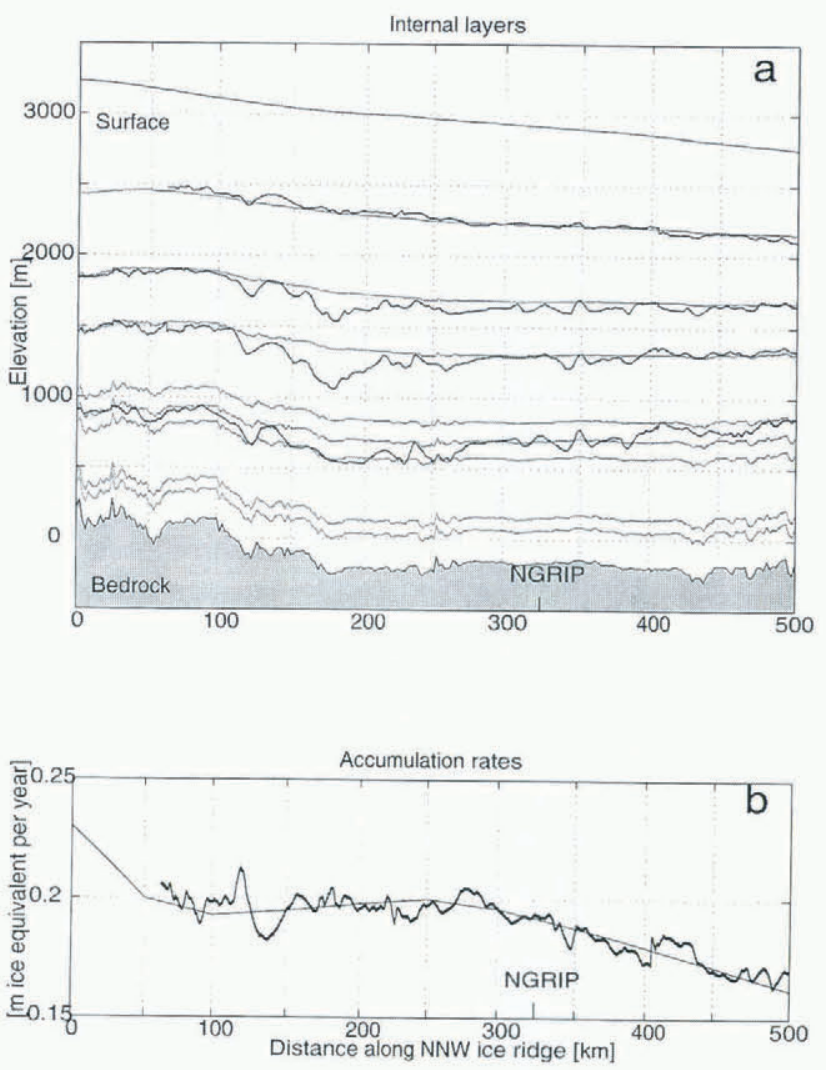

Fig. 2. (a) Surface and bedrock contours and observed radioecho layers (thick black curves) along the ice ridge trending NNW from GRIP from which distances are measured. The modeled internal layers (gray) have the ages 4, 8.6, 14.5, 36, $44,52,115$ and $130 \mathrm{ka} \mathrm{BP}$ (calendar years). (b) Surface accumulation rates ( $m$ ice equivalent year ${ }^{\prime}$ ) used in the flow

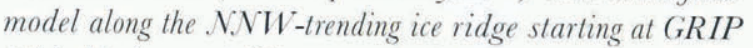
(thin black curve). The accumulation rates are based on the observed accumulation rates from shallow ice cores in the region (Clausen and others, 1988; Ohmura and Reeh, 1991; Bolzan and Stroebel, 1994; Friedmann and others, 1995; personal communication from S. Kipfstuhl, 1996). The thick black curve shows the accumulation rates reconstructed from the upper observed isochrone (4033 years BP) in Figure $2 a$. The good agreement between the two curves shows that the accumulation rates have persisted for several thousand years.

The most crucial parameter, the surface accumulation rate, is poorly known in north Greenland. The available data have been compiled by Ohmura and Rech (1991). Data from the Summit region (Clausen and others, 1988; Bolzan and Stroebel, 1994; Friedmann and others, 1995) and from S. Kipfstuhl (personal communication, 1996), have been used to improve our knowledge of the accumulation rates along the NNW-trending ice ridge (Fig. 2b). There is a decrease in 
accumulation rates just north of the summit (GRIP site); after this drop the accumulation rate stays relatively constant. Accumulation rates vary significantly across the NNW-trending ice ridge, with a decreasing gradient of $0.07 \mathrm{~m}$ ice equivalent year ${ }^{-1}$ per $100 \mathrm{~km}$ toward the northeast.

\section{MODELING OF INTERNAL LAYERS ALONG THE NNW-TRENDING ICE RIDGE}

To calculate the depth of layers of equal age (isochrones) along the NNW-trending ice ridge starting at the GRIP drill site, we use a model similar to that used to date the GRIP ice core. We calculate the ice flow using a modified Dansgaard-Johnsen (DJ) model (Dansgaard and others, 1993) where the vertical strain rate is assumed to be constant from the surface $S(x)$ to a height above bedrock $h(x)$. It then decreases linearly to 0 at the bedrock $B(x)$. The input to the model is a $150 \mathrm{ka}$ accumulation-rate history calculated from the $\delta^{18} \mathrm{O}$ measured in the GRIP ice core (Dahl-Jensen and others, 1993; Johnsen and others, 1995b). The flow model is used along the NNW ice ridge, and the GRIP accumulation history is used along the ridge scaled by the ratio of the present accumulation rates at the site to those at GRIP. Transverse horizontal velocities are assumed to be zero along the line. The ice-divide ridge has a mean slope of $1 \times 10^{-3}$ along its $500 \mathrm{~km}$ length north of GRIP. The horizontal velocities parallel to the sloping ice ridge are believed to be related to the surface slope. Simple calculations show that over the $150 \mathrm{ka}$ considered here, the horizontal ice movement along the ice ridge was no more than $10 \mathrm{~km}$, which does not affect the projected location of the isochrones shown in Figures $2 \mathrm{a}$ and $3 \mathrm{a}$. The horizontal ice movement along the ridge is thus ignored.

The isochrones in Figure 2a have been modeled so that the upper one is aged 4033 years BP (2045 BC), the next two are aged 8596 years BP $(6608 \mathrm{BC})$ and $14.5 \mathrm{ka} \mathrm{BP}$ (the transition between the glacial period and the onset of the Bølling-Allerød period), then follow three layers at GRIP depths of 2200, 2324 and $2421 \mathrm{~m}$, corresponding to ages of 36,44 and $52 \mathrm{ka} \mathrm{BP}$, which coincide with three very prominent transitions in the interstadials (Johnsen and others, in press). The two deepest modelled isochrones, at 115 and $130 \mathrm{ka} \mathrm{BP}$, are chosen because they represent the top and bottom of the Eemian ice, as seen in the GRIP ice core (Dansgaard and others, 1993).

From Figure $2 \mathrm{a}$ it can be seen that the upper modeled isochrones follow the surface with depths influenced by the changing surface accumulation rates as shown in Figure $2 b$. The deeper isochrones are seen to follow the bedrock elevations, but they are influenced by surface accumulation rates and ice thickness as shown in Figure 3a.

Figure 3 a shows the depths of the isochrones and the ice thickness along the ridge. The depth of the $14.5 \mathrm{ka} \mathrm{BP}$ isochrone is seen to decrease from $1750 \mathrm{~m}$ at GRIP to $1650 \mathrm{~m}$ $100 \mathrm{~km}$ north of GRIP, because there is a drop in the surface accumulation rate from 0.23 to $0.19 \mathrm{~m}$ ice equivalent year ${ }^{-1}$. From 100 to $350 \mathrm{~km}$ the depth of the modeled isochrone is approximately constant. The elevation above bedrock of the isochrones defining the top and bottom of the Eemian layer and the thickness of the layer are shown as gray curves in Figure $4 \mathrm{a}$ and b. The decreasing surface accumulation rate increases both the height and the thickness of the
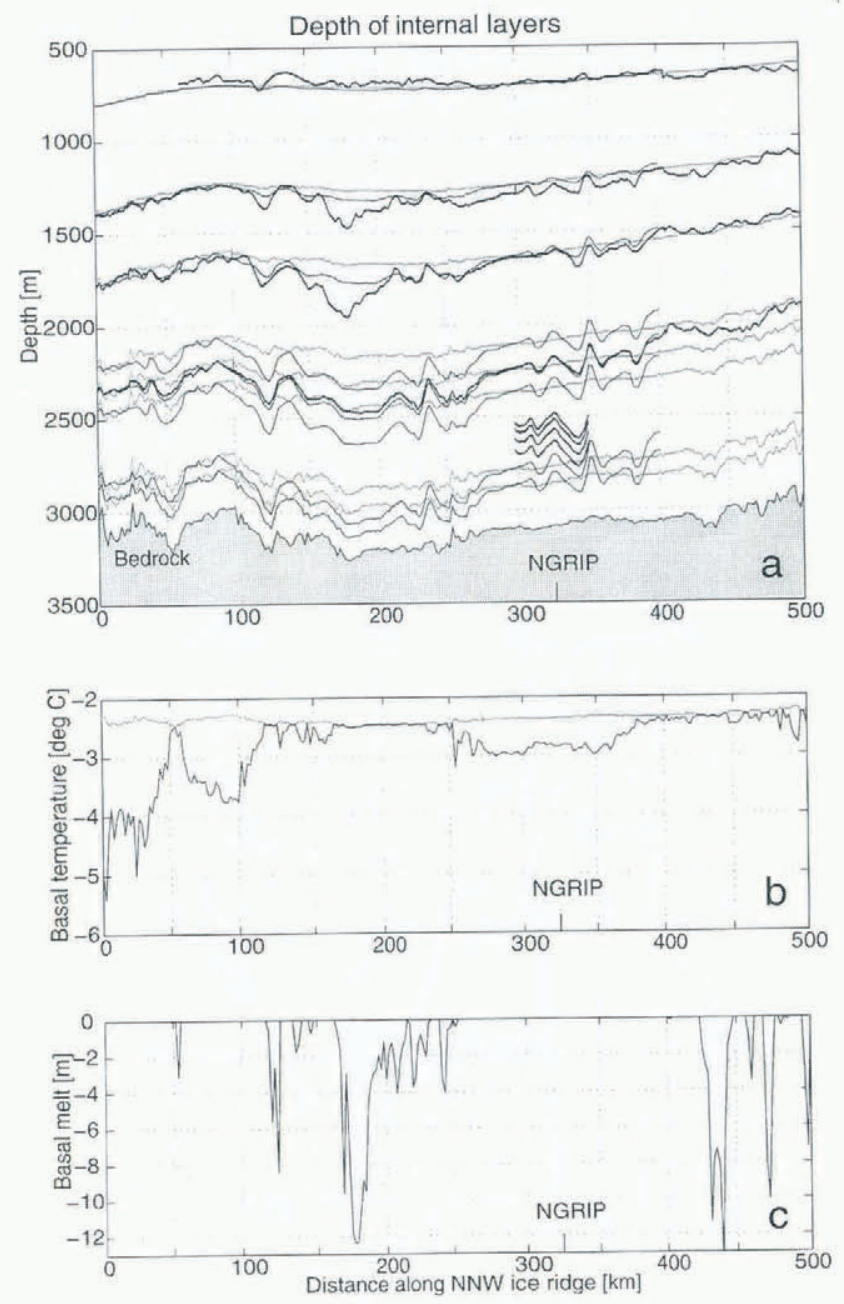

Fig. 3. (a) Ice depths along the NNW ridge from GRIP. The depths of the modeled (gray) and observed (thick black) internal layers also shown in Figure $2 a$ are included. In order to explain the dips between the observed and modeled layers (shaded areas), a refined model simulation of the internal layers has been included as thin black curves. (b) The modeled maximum basal temperatures (gray) reached during the last $150 \mathrm{ka}$ along the ice ridge, compared with the pressuremelting temperatures (black). When the basal temperatures have reached the melting point during the glacial, basal melting has occurred. (c) Estimated amount of total basal melt during the last $150 \mathrm{ka}$; the curve is seen to match the dips.

Eemian layer over the first $100 \mathrm{~km}$, after which it stays nearly unchanged over the following $400 \mathrm{~km}$.

\section{INTERNAL RADIO-ECHO SOUNDING REFLECTORS}

A way to improve our knowledge on the expected location of ice in the ice sheet is to track internal layers observed from radio-echo sounding imagery over the Greenland ice sheet. Several sets of radio-echo data have been collected from north Greenland (Gudmandsen, 1975; Hempel and Thyssen, 1993; Jacobel and Hodge, 1995; Chuah and others, 1996), and all clearly show internal layering. The internal layers are recognized as internal reflecting surfaces of the same age (i.e. isochrones). The cause of the reflections has been discussed by several researchers (Hammer, 1980; Moore, 1988; Hempel and Thyssen, 1993; Fujita and Mae, 1994), who conclude that changes in ice conductivity are 

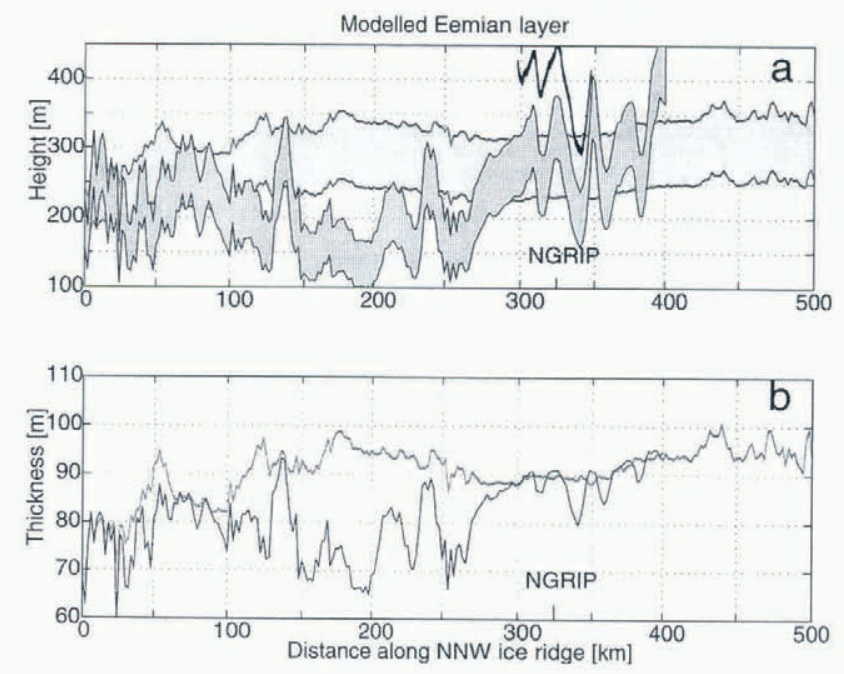

Fig. 4. The modeled location of the Eemian layer is shown by (a) the distance above bedrock of ice aged 115-30 ka BP, and (b) the thickness of this layer along the ice ridge from GRIP trending $\mathcal{N N W}$. The gray curves enclosing light shading represent the basic model results, while the black curves enclosing dark shading show the refined model results. In (a) the lowest-lying internal radio-echo sounding reflector is included as a thick black curve in the region close to the NGRIP site, $316 \mathrm{~km}$ from GRIP. The $115 \mathrm{ka}$ top boundary of the Eemian layer traces this reflector well, which gives us confidence in the model predictions.

responsible for the dielectric contrast producing these reflections and that acidic fallout from volcanic eruptions and changes in impurity concentrations, that accompany the sudden climatic transitions, are the most likely source of these changes. In most of the radio-echo records, some general structures can be identified that can be traced over large distances.

Figure 5a and b show examples of the radio-echo sounding profiles collected in 1995 and 1996 by NASA and Kansas University (Chuah and others, 1996) along the flight-lines shown in Figure 1. The profile in Figure 5a is along a line $50 \mathrm{~km}$ east of the NNW ridge from $74.62^{\circ} \mathrm{N}, 40.54^{\circ} \mathrm{W}$ to $75.83^{\circ} \mathrm{N}, 42.19^{\circ} \mathrm{W}$, which is approximately $200-400 \mathrm{~km}$ from GRIP. The profile in Figure $5 \mathrm{~b}$ is a $50 \mathrm{~km}$ long line along the NNW ridge from $74.88^{\circ} \mathrm{N}, 41.90^{\circ} \mathrm{W}$ to $75.30^{\circ} \mathrm{N}$, $42.48^{\circ} \mathrm{W}$ that passes just $2 \mathrm{~km}$ east of the NGRIP site.

The depth interval $100-700 \mathrm{~m}$ has been blocked in data processing to obtain the maximum possible resolution of the deep-lying reflectors. The shallowest reflector identified occurs at a depth of $700 \mathrm{~m}$ on most of the images and can be recognized in the GRIP ice core as a volcanic horizon 4033 years BP (Clausen and others, in press). Another very prominent reflector is found at a depth of $1300 \mathrm{~m}$ and is believed to be a strong volcanic horizon 8596 years BP. A gap is observed beginning at a depth of $1600 \mathrm{~m}$. The transition between the more prominent internal reflectors and the gap coincides with the onset of the Bolling-Allerod $14.5 \mathrm{ka} \mathrm{BP}$ (Hammer, 1980; Hempel and Thyssen, 1993). The gap with weak or no reflectors thus coincides with ice from the cold Last Glacial Maximum. Three layers can be identified clearly $700-1100 \mathrm{~m}$ above bedrock. These have been discussed in Gudmandsen (1975) and Jacobel and Hodge (1995) and can be tracked in most of the radio-echo data from North Greenland (Rishøjgaard, 1989). Gudmandsen (1975)
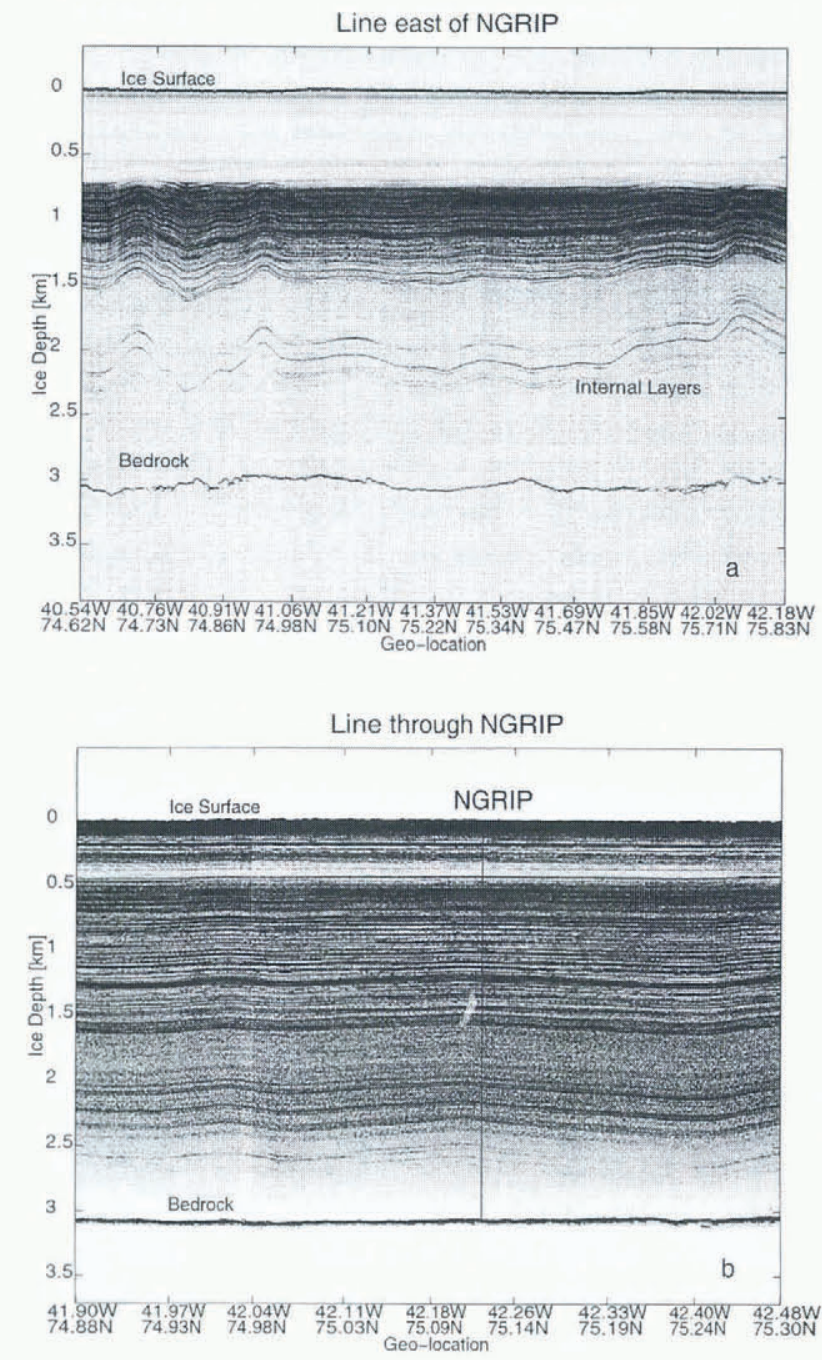

Fig. 5. (a) $A 100 \mathrm{~km}$ section of the radio-echo imagery collecled in 1995 with the $150 \mathrm{MHz}$ CARDs system (Chuah and others, 1996) along a profile $50 \mathrm{~km}$ east of the .NNW ridge (long thick line in Fig. I). Here the accumulation rate is reduced to $0.18 \mathrm{~m}$ ice equivalent year ${ }^{-1}$, and large oscillations of the internal layers are observed because the basal temperatures approached the melting point during the glacial period. (b) A $50 \mathrm{~km}$ profile collected in 1996 with the same system. The profile passes $2 \mathrm{~km}$ east of the NGRIP site (short thick line in Fig. 1). The reflectors can be dated by tracing them to the dated GRIP ice core. In this way, the internal reflectors date the ice in north Greenland at the depths where the internal layers are observed.

and Hempel and Thyssen (1993) suggest that the reflectors are sharp transitions associated with the interstadials. The radio-echo sounding reflectors can be traced back to the GRIP site, where the ice core has been dated. In Figure 5b some very weak reflectors are observed $300-500 \mathrm{~m}$ from the bedrock. These can be seen only on the radio-echo profiles from 1996, so they cannot be tracked back to the GRIP site.

\section{COMPARISON OF OBSERVED AND MODELED INTERNAL LAYERS}

In Figure 5a the oscillations of the elevations of the three deep-lying reflectors 700-1000 $\mathrm{m}$ above bedrock are unexpected. These oscillations are not generated by bedrock undulations, as the bed is quite smooth here and no surface 
undulations support the internal oscillations. In addition, the oscillations are less pronounced in shallower layers. The oscillations could be caused by variations of the surface accumulation rates or by variations of the dynamic velocity fields along the ridge.

Variations of the surface accumulation rates could be caused by movement in the east-west direction of the NNW-going ice ridge back in time. The flow model described earlier is used to model the flow along the line shown in Figure 5a, $50 \mathrm{~km}$ east of the NNW ice ridge. The surface accumulation rate is known to be $0.18 \mathrm{~m}$ ice equivalent year ${ }^{-1}$ in this region, and the model results reveal that the accumulation rate must vary between 0.14 and $0.19 \mathrm{~m}$ ice equivalent year ${ }^{-1}$ along the line in order to generate oscillations of the observed magnitude $700-800 \mathrm{~m}$ above bedrock. This seems unlikely as the surface contours and the accumulation pattern are so smooth in this region, and it would be difficult for ice-ridge movements to produce this pattern.

To explore the possibility of variations in the velocity field along the ridge, we have calculated a 150 ka history basal temperature using a thermodynamic ice-flow model (Dahl-Jensen and others, 1993; Johnsen and others, 1995a) driven by the surface temperature and accumulation-rate histories generated from the GRIP stable-isotope record (Johnsen and others, 1995a). Since the present surface accumulation rate decreases towards the north, the accumulation-rate history from GRIP is scaled at each site by the present accumulation rate between that site and GRIP. The present surface temperature is nearly constant in this considered region of north Greenland, so the GRIP surface temperature history can be used over the entire flowline. The modeled basal temperature increases as the surface accumulation rates decrease, because less cold snow moves down into the ice sheet. Where the present surface accumulation rate is less than $0.18 \mathrm{~m}$ ice equivalent year ${ }^{-1}$, the basal ice reaches the pressure-melting point during the glacial for an ice thickness of $3000 \mathrm{~m}$. Increasing ice thickness increases the basal temperature by approximately $2{ }^{\circ} \mathrm{C}$ per $100 \mathrm{~m}$. The warmest basal temperatures are reached during the glacial and are roughly $2.5^{\circ} \mathrm{C}$ warmer than the present basal temperatures. The radio-echo sounding profile shown in Figure $5 \mathrm{a}$ is in a region where the present surface accumulation rate is $0.18 \mathrm{~m}$ ice equivalent year ${ }^{-1}$ and the ice thickness is fairly constant. Basal melting thus could have occurred during the glacial.

When the basal ice is close to the pressure-melting point, both bottom sliding and basal melting can occur. Both processes drag the internal layers downward. Basal sliding allows layer thinning right down to the bedrock, and basal melting moves the layers right down to the bedrock. We can match the observed oscillating internal layers by varying $h(x)$, the height above which the vertical strain rate is assumed to be constant in the DJ model, between 400 and $2000 \mathrm{~m}$ and allowing $10-70 \%$ of the horizontal velocity to be basal sliding and simulating sliding and non-sliding conditions. Non-sliding is believed to have occurred where the internal layers are located furthest from bedrock, while sliding is believed to have dragged the layers downwards in the remaining regions.

Sliding does not appear to have taken place everywhere along the profile in Figure 5a. When the ice is close to the pressure-melting point, small spatial variations in geothermal heat flux could create the spatially variable sliding pattern. Geothermal flux would be expected to vary with bedrock geology.

We conclude that the second explanation of the internal oscillations, as being a result of varying velocity fields, is preferred. The first explanation is rejected because we would have to assume unreasonably large variations in the surface accumulation rate. Also the internal oscillations generated by sliding/non-sliding conditions will increase with depth, while the oscillations generated by variations of the surface accumulation rate will decrease when bedrock is approached. For the selection of a drill site whose prime objective is to study the deep-lying ice, it is very important to avoid the zones where basal temperatures approach the pressure-melting point.

The observed internal layers along the NNW-trending ice ridge are included in Figures $2 \mathrm{a}$ and $3 \mathrm{a}$ as thick black lines. The upper reflector at $700 \mathrm{~m}$ depth (4033 years BP) can be used to determine if reasonable accumulation-rate values have been used in the calculations, as this layer is nearly unaffected by the bedrock and possible variations of the velocity fields. The reconstructed surface accumulation rate from the upper internal layer is shown in Figure $2 \mathrm{~b}$ as a thick black curve. This curve, which represents the accumulation during the last 4000 years, is seen to agree reasonably with the accumulation-rate profile used in the calculations. This confirms that the significant drop of the accumulation rate $50 \mathrm{~km}$ north of GRIP, as reported by Bolzan and Stroebel (1994), who used $20 \mathrm{~m}$ deep shallow ice cores containing firn from 50 years' accumulation, has persisted for a long time.

The age of the modeled isochrones shown in Figures 2a and $3 \mathrm{a}$ (thick gray curves) has been chosen so they have the same age as the observed radio-echo sounding reflectors between the GRIP and the NGRIP drill sites. The reflectors are seen to compare well with the modeled isochrones except at 100-270 km from GRIP along the NNW-trending ice ridge. Here all the reflectors dip simultaneously up to several hundred meters. The surface accumulation rate is $0.19 \mathrm{~m}$ ice equivalent year ${ }^{-1}$ here, but the ice thickness can be seen to increase to $3250 \mathrm{~m} 175 \mathrm{~km}$ from GRIP where the greatest dip is found. This ice-thickness increase will result in basal temperatures reaching the pressure-melting point during the glacial period. Figure $3 \mathrm{~b}$ compares the maximum basal temperatures, which are reached during the glacial, with the ice-thickness-related pressure-melting point. In regions where basal temperatures reach the melting point the amount of ice that has been melted during the last glacial is shown in Figure 3c. Basal melt occurs in regions where the reflectors are seen to dip, and the amount of predicted basal ice melted shown in Figure $3 \mathrm{c}$ has the same shape as the dips (shaded areas in Figure 3a). The internal layers may be dragged down here due to changes of the velocity fields caused by basal melting conditions, as discussed earlier, for the line lying $50 \mathrm{~km}$ to the east (Fig. $5 \mathrm{a})$.

A refined modeling of the observed radio-echo reflectors has been attempted by adjusting the dynamic velocity fields to sliding and non-sliding conditions along the line, as discussed earlier. The refined modeled layers are shown as thin black curves in Figure 3a. They are seen to match the oscillations of the internal layers at all depths except 150 $200 \mathrm{~km}$, where the layers dip most. Around the NGRIP site, $316 \mathrm{~km}$ from GRIP, the refined model layers can be compared with the deep reflectors (depths 2500-2750 m) from 
Figure $5 \mathrm{~b}$. The refined model dates these reflectors to $80-$ $100 \mathrm{ka}$ BP. The top and bottom of the modelled Eemian layers are shown as thin black curves in Figure 3a. The amplitude of the small oscillations of the thin black curves is seen to agree well with that from the observed deep reflectors, which gives confidence in the predicted location of the Eemian layer in the NGRIP ice core.

\section{DISCUSSION}

We are searching for an ice-core site in Greenland where a reduced accumulation rate raises and thickens the Eemian ice layer while avoiding basal melting. The region upstream of the site should have flat bedrock to reduce oscillations of the internal layers. The site should be on an ice ridge to ensure minimum horizontal velocity and in the center part of the ice sheet to reduce possible ice-thickness changes back in time.

Calculations with a thermomechanical flow model indicate that when the surface accumulation rate drops below $0.18 \mathrm{~m}$ ice equivalent year ${ }^{-1}$, the pressure-melting point is reached for an ice thickness similar to that found at GRIP $(3027 \mathrm{~m})$. The ice thickness also affects the basal temperature, so an increase of $100 \mathrm{~m}$ results in a $2^{\circ} \mathrm{C}$ warming of the basal ice.

Taken together, it is clear that we restrict favorable coring sites to a very small region. A poor selection could result in a site where the ice from the Eemian period has been dragged down to the bedrock and the oldest ice is melted away instead of being elevated.

The modeled prediction of the height and thickness of the Eemian layer (115-130 ka BP) along the NNW-trending ice ridge starting at GRIP is shown in Figure $4 \mathrm{a}$ and b as gray curves. The major elevation and increase of thickness happens during the first $50 \mathrm{~km}$ because the surface accumulation rate decreases from 0.23 to $0.19 \mathrm{~m}$ ice equivalent year $^{-1}$. From 50 to $400 \mathrm{~km}$ there are small changes in the location of the Eemian layer. There is a region $50-250 \mathrm{~km}$ from GRIP where the observed reflectors dip up to $200 \mathrm{~m}$ when compared to their modeled positions. In this region the ice thickness increases to $3250 \mathrm{~m}$, causing the basal temperature to approach the pressure-melting point. Between 275 and $390 \mathrm{~km}$ north of GRIP the ice thickness decreases and the modeled and observed internal layers agree again. Further north the accumulation rate drops, so basal ice again can be expected to reach the pressure-melting point. A refined modeling of the position of the Eemian layer (black curves in Figure $4 \mathrm{a}$ and b) allows us to match the observed reflectors except between 150 and $200 \mathrm{~km}$, where the dip is greatest. The Eemian layer is first seen to rise at $275 \mathrm{~km}$ distance from GRIP north of the region where basal melting probably has occurred. The deepest observed radio-echo sounding reflector is included as a thick black curve in Figure 4 a because it demonstrates the reliability of the refined modeling of the position of the Eemian layer around NGRIP.

The age-depth profile for the NGRIP site, modeled by the refined model, is shown in Figure 6b. Here the stableisotope profile, $\delta^{18} \mathrm{O}$, measured and dated on the GRIP ice core (Fig. 6a), has been transferred to the NGRIP site. The radio-echo layers discussed in the previous sections are also shown. The transition from Holocene to glacial ice is predicted to be found at a depth of $1460 \mathrm{~m}$. For ice younger than

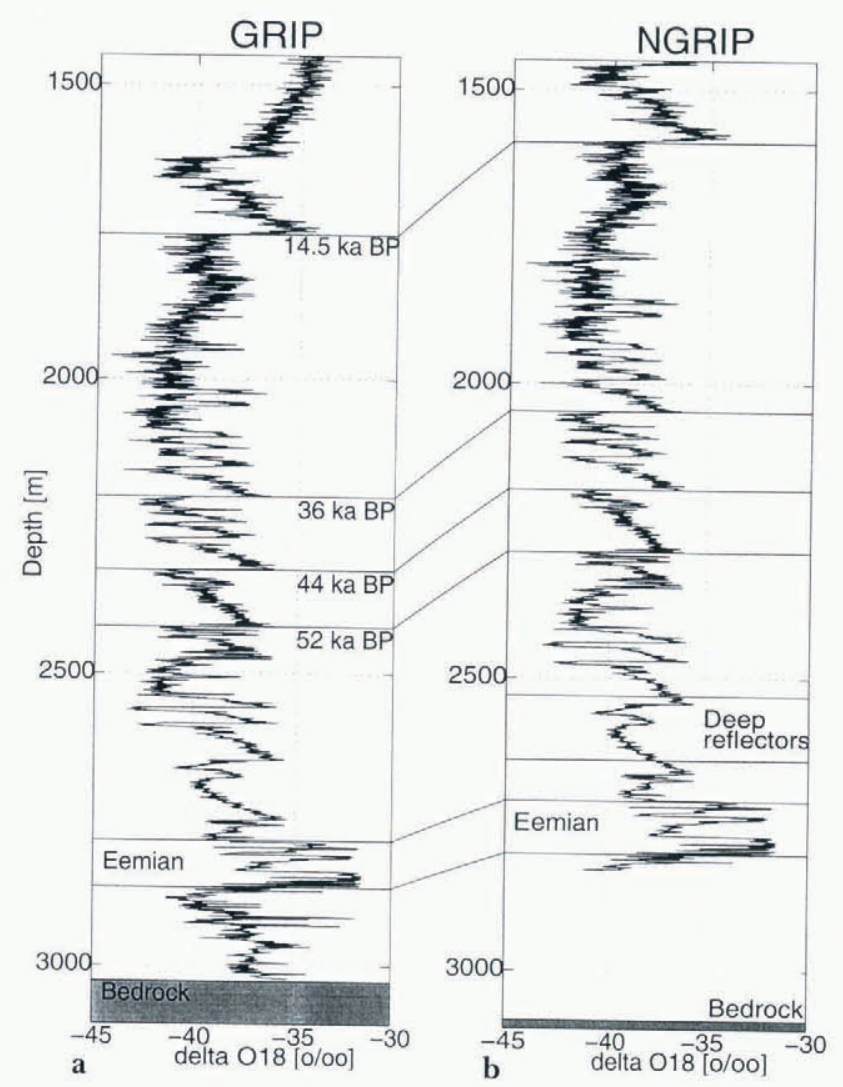

Fig. 6. Simulations of the expected time-scale at NGRIP with the refined model. The $\delta^{18} \mathrm{O}$ profile measured on the GRIP ice core is plotled on the NGRIP time-scale. The NGRIP "climate curve" (Fig. 6b) is compared to the GRIP "climate curve" (Fig. 6a). The internal radio-echo reflectors that have been traced between the GRIP and the NGRIP site $(14.5,36$, 44 and $52 \mathrm{ka} \mathrm{BP}$ ) ensure that the predicted depth age profile at NGRIP is correct down to $2300 \mathrm{~m}$ depth. The depth interval where the deep reflectors are observed on the radio-echo imagery from 1996 ( Fig. 5b) demonstrates that the ice is still layered at depths just above the Eemian ice at NGRIP.

$40 \mathrm{ka}$, layer thicknesses at NGRIP are thinner than at GRIP; the situation is reversed for older ice.

\section{CONCLUSIONS}

We suggest that a drill site should be located $275-375 \mathrm{~km}$ from GRIP along the NNW-trending ice ridge. The NGRIP ice core is now being drilled in the region $75.120^{\circ} \mathrm{N}$, $42.350^{\circ} \mathrm{W}(316 \mathrm{~km}$ from GRIP along the NNW-trending ice ridge) where the surface elevation is $2919 \mathrm{~m}$, ice thickness is $3085 \mathrm{~m}$ and the surface accumulation rate is $0.190 \pm 0.005 \mathrm{~m}$ ice equivalent year ${ }^{-1}$. The bedrock is smooth in this region (Fig. 5b).

The deepest layer that can be traced to GRIP is found $700 \mathrm{~m}$ above the bedrock at the NGRIP site, and has an age of $52 \mathrm{ka}$. Because our modeled ages for all the traceable layers agree well with the dates at GR IP, we can confidently use the flow model to date the deeper reflectors (Figs $5 \mathrm{~b}$ and $3 \mathrm{a}$ at $500-300 \mathrm{~m}$ above bedrock to $80-100 \mathrm{ka}$, respectively.

Using these layers dated by the GRIP core, we have produced a depth-age scale for the NGRIP core that is well constrained by data to $52 \mathrm{ka}$, and confidently dated to $100 \mathrm{ka}$ by flow modeling (Fig. 6). The layers confirm that 
the ice $300 \mathrm{~m}$ above the bed has not been significantly disturbed.

The ice from the Eemian period 115-135 ka BP should be found at depths of $2750-2850 \mathrm{~m}$ at NGRIP. The sequence is $20 \mathrm{~m}(25 \%)$ thicker than the Eemian sequence at GRIP. The onset of the Eemian period (135 ka BP) should be found $235 \mathrm{~m}$ above bedrock at NGRIP; this is $120 \mathrm{~m}$ higher above the bed than the Eemian ice at GRIP. Therefore, we expect the NGRIP site to offer a significantly better opportunity to recover an undisturbed Eemian sequence than the Summit region (GRIP and GISP2), and possibly the best opportunity anywhere in the Greenland ice sheet. The NGRIP drilling commenced in 1996, and reached a depth of $354 \mathrm{~m}$. When then bedrock is reached, we will know!

\section{ACKNOWLEDGEMENTS}

Funding of the NGRIP program by the Danish Science Foundation has made this work possible. The U.S. National Science Foundation - Office of Polar Programs grant 9123660 supported E. Waddington's contribution to the research and allowed D. Dahl-Jensen to visit Seattle over several periods to work on the paper. Suggestions from D. MacAyeal have improved the paper. The NASA flights along the ice ridge in 1995 and 1996, where the radio-echo sounding profiles were collected, were most valuable for the selection of the NGRIP drill site, for which we thank NASA and the University of Kansas.

\section{REFERENCES}

Alley, R. B., A.J. Gow, S.J. Johnsen, J. Kipfstuhl, D. A. Meese and Th. Thorsteinsson. 1995. Comparison of deep ice cores. Nature, 373 (6513), 393-394.

Alley, R. B., A. J. Gow, D. A. Meese, J. J. Fitzpatrick, E. D. Waddington and J.F. Bolzan. In press. Grain-scale processes, folding and stratigraphic disturbance in the GISP2 ice core. 7. Geophys. Res..

Bolzan, J. F. and M. Strobel. 1994. Accumulation-rate variations around Summit, Greenland. 7. Glaciol., 40 (134), 5666.

Chuah, T. S., S. P. Gogineni, C. Allen and B. Wohletz. 1996. Radar thickness measurements over the northern part of the Greenland ice sheet. Lawrence, KS, University of Kansas. Radar Systems and Remote Sensing Laboratory. (Technical Report 10470-3.

Clausen, H. B., N. S. Gundestrup, S.J. Johnsen, R. Bindschadler and J. Zwally. 1988. Glaciological investigations in the Crète area, central Greenland: a search for a new deep-drilling site. Ann. Glaciol., 10, 10-15.

Clausen, H. B., C. U. Hammer, C. S. Hvidberg, D. Dahl-Jensen, J. P. Steffensen and M. Legrand. In press. Comparison of the GRIP and DYE3 volcanic records over 400 years. 7. Geophys. Res.

Dahl-Jensen, D., S. J. Johnsen, C. U. Hammer, H. B. Clausen and J. Jouzel. 1993. Past accumulation rates derived from observed annual layers in the GRIP ice core from Summit, central Greenland. In Peltier, W. R., ed. Ice in the climate system. Berlin, etc., Springer-Verlag, 517-532. (NATO
ASI Series I: Global Environmental Change 12.

Dansgaard, W. and 10 others. 1993. Evidence for general instability of past climate from a 250-kyr ice-core record. Nature, 364 (6434), 218-220.

Ekholm, S. 1996. A full coverage, high resolution topographic model of Greenland computed from a variety of digital elevation data. 7. Geophys. Res., 101 (B10), 21,961-21,972

Ekholm, S., R. Forsberg and J. M. Brozena. 1995. Accuracy of satellite altimeter elevations over the Greenland ice sheet. J. Geoplys. Res., 100 (C2), $2687-2696$.

Fabre, A., A. Letréguilly, C. Ritz and A. Mangeney. 1995. Greenland under changing climates: sensitivity experiments with a new three-dimensional ice-sheet model. Ann. Glaciol., 21, 1-7.

Fahnestock, M., R. Bindschadler, R. Kwok and K. Jezek. 1993. Greenland ice sheet surface properties and ice dynamics from ERS-1 SAR imagery. Science, 262 (5139), 1530-1534.

Friedmann, A., J. C. Moore, T. Thorsteinsson, J. Kipfstuhl and H. Fischer. 1995. A 1200 year record of accumulation from northern Greenland. Ann. Glaciol., 21, $19-25$.

Fujita, S. and S. Mae. 1994. Causes and nature of ice-sheet radio-echo internal reflections estimated from the dielectric properties of ice. Ann. Glaciol., 20, 80-86.

Grootes, P. M., M. Stuiver, J. W. C. White, S. Johnsen and J. Jouzel. 1993. Comparison of oxygen isotope records from the GISP2 and GRIP Greenland ice cores. Nature, 366 (6455), 552-554.

Gudmandsen, P. 1975. Layer echoes in polar ice sheets. J. Glaciol., 15 (73), 95-101.

Hammer, C. U. 1980. Acidity of polar ice cores in relation to absolute dating, past volcanism, and radio-echoes. f. Glaciol., 25 (93), 359-372.

Hempel, L. and F. Thyssen. 1993. Deep radio echo soundings in the vicinity of GRIP and GISP2 drill sites, Greenland. Polarforschung, 62 (1), 1992, 11-16.

Hodge, S. M., D. L. Wright, J. A. Bradley, R. W. Jacobel, N. Skou and B. Vaughn. 1990. Determination of the surface and bed topography in central Greenland. 7. Glaciol., $36(122), 17-30$.

Jacobel, R.W. and S. M. Hodge. 1995. Radar internal layers from the Greenland summit. Geophys. Res. Lett., 22(5), 587-590.

Johnsen, S. J. and 9 others. 1992. Irregular glacial interstadials recorded in a new Greenland ice core. Nature, 359 (6393), 311-313.

Johnsen, S. J., H. B. Clausen, W. Dansgaard, N. S. Gundestrup, C.U. Hammer and H. Tauber. 1995a. The Eem stable isotope record along the GRIP ice core and its interpretation. Quat. Res., 43 (2), 117-124.

Johnsen, S. J., D. Dahl-Jensen, W. Dansgaard and N. S. Gundestrup. 1995b. Greenland paleotemperatures derived from GRIP borehole temperature and ice core isotope profiles. Tellus, 47B (5), 624-629.

Johnsen, S.J. and 9 others. In press. The GRIP stable isotope record. J. Geophys. Res.

Letréguilly, A., N. Reeh and P. Huybrechts. 1991a. The Greenland ice sheet through the last glacial interglacial cycle. Palaeogeogr., Palaeoclimatol., Palaeoecol., 90 4), 385-394.

Letréguilly, A., P. Huybrechts and N. Reeh. 1991b. Steady-state characteristics of the Greenland ice sheet under different climates. J. Glaciol., $37(125), 149-157$.

Moore, J. C. 1988. Dielectric variability of a $130 \mathrm{~m}$ Antarctic ice core: implications for radar sounding. Ann. Glaciol., 11, 9599.

Ohmura, A. and N. Rech. 1991. New precipitation and accumulation maps for Greenland. J. Glaciol., 37 (125), 140-148.

Rishojgaard, L. 1989. En undersøgelse af interne lag i central-gronlandske radioekkodata. (M.Sc. thesis, University of Copenhagen.

Taylor, K. C. and 9 others. 1993. Electrical conductivity measurements from the GISP2 and GRIP Greenland ice cores. Nature, 366 (6455), $549-552$.

Thorsteinsson, T., J. Kipfstuhl and H. Miller. In press. Texture and fabrics in the GRIP ice core. J. Geophys. Res.. 